\title{
Soil Physical Quality After 21 Years of Cultivation in a Brazilian Cerrado Latosol
}

\author{
Aristides O. Ngolo ${ }^{1}$, Maurílio F. Oliveira ${ }^{2}$, Igor R. Assis ${ }^{1}$, Genelício C. Rocha ${ }^{1} \&$ Raphael B. A. Fernandes ${ }^{1}$ \\ ${ }^{1}$ Soil Science Department, Universidade Federal de Viçosa, Viçosa, MG, Brazil \\ ${ }^{2}$ Embrapa Milho e Sorgo, Empresa Brasileira de Pesquisa Agropecuária, Sete Lagoas, MG, Brazil \\ Correspondence: Raphael B. A. Fernandes, Soil Science Department, Universidade Federal de Viçosa, Viçosa, \\ MG, 36570-900, Brazil. E-mail: raphael@ufv.br
}

Received: November 23, 2018

Accepted: December 27, 2018

Online Published: February 15, 2019

doi:10.5539/jas.v11n3p124

URL: https://doi.org/10.5539/jas.v11n3p124

\begin{abstract}
Long-term studies aiming soil quality evaluation under different soil management strategies are no common. Long-term evaluations provided more reliable contributions to decision-making and practices adoption. This study evaluated the soil physical quality of a Brazilian Cerrado Latosol after 21 years of three different soil management strategies: disc plowing (DP), no-tillage (NT), and disc harrowing+subsoiling (DHS). In comparison to the reference, a soil from a native Cerrado area, the removal of the original vegetation and the implementation of the three soil management strategies increased the soil bulk density (Bd) and reduced soil porosity, macroporosity, soil organic carbon (SOC) and the size of water-stable aggregates, but did not change the glomalin-related soil protein (GRSP) contents and clay flocculation. Similar effects were diagnosed on soil physical quality when is considered only the three different management strategies, especially on soil porosity, Bd, size of water-stable aggregates, SOC and GRSP contents. Strategies of DP and NT increased soil resistance to penetration in the superficial layers, while the annual use of DHS reduced this soil mechanical characteristic. The NT system did not provide increasing of soil organic carbon in comparison to other management practices evaluated. In conclusion, removing the native vegetation affected soil physical quality, but the Brazilian Cerrado soil is resilient to physical damage even when different intensive farming practices are implemented for more than two decades. The limitation of the NT system in improving the soil physical quality is related to climate conditions that determine the non-maintenance of straw on the soil surface.
\end{abstract}

Keywords: conservation agriculture, long-term cultivation, no-tillage

\section{Introduction}

The Latosols in the Cerrado biome located in the central region of Brazil are well-developed pedogenetically, homogeneous, and present small variations between horizons. The natural fertility of these soils is low; however, physical characteristics such as drainage and depth are adequate, which make them very useful for agricultural production. The soil management systems adopted in this region have been more focused on increasing productivity by adopting technological innovations and intensifying land use. In contrast, the Brazilian Cerrado is considered one of the world's biodiversity hotspots, constituting the second largest biome of the South American continent and covering an area of 2,036,448 $\mathrm{km}^{2}$ in states in the north, northeast, midwest, south, and southeast regions of Brazil (MMA, 2018).

In contrast to air and water quality, which is measured by its degree of contamination (Andrews et al., 2002), soil quality is defined by its ability to function within the limits of the ecosystem and land use to ensure biological productivity, maintaining environmental quality, and promoting plant and animal health (Doran \& Parkin, 1994).

The conversion of native vegetation areas into cultivated areas changes the physical, chemical, and biological characteristics of the soils. A common trend is the worsening of attributes related to the soil physical quality, especially the increase in soil compaction, and consequently the increase in erosion and decrease in infiltration rate, and the reduction of soil volume explored by plants (Spera et al., 2004). Only the cultivation practices can promote soil losses from erosion, as indicated by Doetterl et al. (2016) as the tillage erosion. This type of erosion produced by intensive and mechanized management can reach levels similar to those of water erosion. 
Loss of soil physical quality is relatively higher in clay soils, where compaction is higher (Horn, 1988). In Brazil, clayed soils are typical in the Cerrado area where technological innovations in agriculture are responsible for success and a significant percentage of the national gross domestic product. Therefore, adopting management and agricultural practices that depreciate the soil physical quality may decrease productivity in this important agricultural region of Brazil.

Soil erosion and degradation are minimized or reduced by using conservative management practices, with an emphasis on no-tillage systems (Wang et al., 2017). According to the Brazilian Federation of No-Tillage Systems, approximately 32 million hectares were planted with summer crops in Brazil before the 2013/2014 harvest under no-tillage systems, and these area size has increased since the beginning of the practice in 1972 (FEBRAPDP, 2018).

Conservation agriculture represented by no-tillage minimizes soil disturbance by reducing the mineralization of organic matter, consequently increasing the organic carbon content and improving soil aggregation and infiltration (Guo et al., 2016).

Impacts resulting from intensive soil management practices have decreased crop productivity, especially when the soil structure is damaged and soil organic matter concentration is decreased (Zhang et al., 2017). In this context, management practices that have a lower impact on the soil and that maintain or increase organic matter concentration are recommended.

The soil organic matter is a critical component associated with the development and maintenance of soil structure and is the focus of different management practices. Several studies demonstrated the role of glomalin-related soil protein (GRSP) in binding soil particles. Sharifi et al. (2018) suggested the use of the ratio between GRSP and soil organic carbon as an indicator of the level of disturbance of crop systems.

The no-tillage system has been highlighted as a conservative soil management practice in Brazil and worldwide, mainly when it is associated with increased soil mulch. This system reduces the risk and rate of erosion and increases soil organic matter, soil infiltration, soil fertility, and overall soil quality (Ogban et al., 2001; Iqbal et al., 2005).

Most studies on the effects of soil management practices on soil quality were short-term and lacked methodological rigor. Long-term studies are rare because of their complexity and costs, which limits the obtaining of results and recommendations with a higher degree of reliability.

The objective of this study was to evaluate the soil physical quality of a Brazilian Cerrado Latosol after 21 years of intensive cultivation under no-tillage and other soil management strategies.

\section{Materials and Methods}

\subsection{Area Description}

This study was carried out in an experimental area of the Brazilian Agricultural Research Company (Embrapa Milho e Sorgo) located in the municipality of Sete Lagoas $\left(19^{\circ} 27.408^{\prime} \mathrm{S}\right.$ and $44^{\circ} 10.939^{\prime} \mathrm{W}$; and $786 \mathrm{~m}$ of altitude), Minas Gerais State, Brazil. According to Köppen's classification, the climate of the region is type Cwa, with dry winter and hot summer, and temperatures above $22{ }^{\circ} \mathrm{C}$ in the hottest month of the year. The soil of the experimental area was classified as clayey Red Latosol (EMBRAPA, 2013) with a very clayey texture (Table 1). The native soil presents limited fertility, but cultivation practices could improve its chemical attributes.

The study area was previously occupied by pastures. From 1995 to 2016, this area was divided into $320 \mathrm{~m}^{2}$ plots $(20 \times 16 \mathrm{~m})$ and used for cultivation under different soil management strategies. In the present study, the areas cultivated using disc plowing (DP), no-tillage (NT), and disc harrowing + subsoiling (DHS) were selected. A nearby and contiguous area with native Cerrado (NC) vegetation (not included in the original experiment) was used as the reference. All evaluated areas, including the NC area, presented similar soil class, slope, landscape position, and face of exposure to solar radiation.

All experimental plots were cultivated with corn, except for NT soils, which was characterized by corn-soybean rotation. The experiment was analyzed considering a completely randomized block design with three replications.

In the DP treatment, the equipment used was a disc plow with three discs (diameter of 32"). A three-shank subsoiler and an intermediate disc harrow with 16 discs (diameter of $28^{\prime \prime}$ ) were used in the DHS treatment. Leveling procedure was performed in DP and DHS treatment using a leveling apparatus after soil preparation. Herbicide glyphosate was applied before cultivation in NT soils for desiccation. This same herbicide was applied to all cultivated areas during the offseason to manage weed growth. All operations were performed using two 
tractors $(4,150 \mathrm{~kg}$ and $5,500 \mathrm{~kg})$.

The corn crop was cultivated $(65,000$ plants/ha) in all areas using a seed and fertilizer spreader. Annual maintenance and cover fertilization and the application of gypsum and limestone were performed according to technical recommendations based on soil analyses. Phytosanitary control in the study area was carried out by applying insecticides, with two to three applications after cultivation according to technical recommendations.

The corn-soybean rotation was performed in NT treatment. In the years of soybean cultivation, a total of 500 $\mathrm{kg} / \mathrm{ha}$ of NPK formulation 4-30-16 was applied to this crop at sowing (280.000 plant/ha). Millet was grown with irrigation in the NT areas in the off-season in the years 2008 and 2010, and the formed and incorporated biomass was $60 \mathrm{t} / \mathrm{ha}$ of green mass. No other crop was used in the off-season of other experiment years.

Table 1 . Soil chemical and physical characteristics of the study areas $(0-0.20 \mathrm{~m}$ depth)

\begin{tabular}{lllll}
\hline & $\mathrm{NC}$ & $\mathrm{DP}$ & $\mathrm{NT}$ & $\mathrm{DHS}$ \\
\hline $\mathrm{pH}\left(\mathrm{H}_{2} \mathrm{O}\right)$ & 4.97 & 4.79 & 5.86 & 5.14 \\
$\mathrm{P}\left(\mathrm{mg} / \mathrm{dm}^{3}\right)$ & 0.5 & 7.6 & 8.63 & 12.77 \\
$\mathrm{~K}\left(\mathrm{mg} / \mathrm{dm}^{3}\right)$ & 16 & 132.33 & 84.67 & 84.67 \\
$\mathrm{Ca}^{2+}\left(\mathrm{cmol}_{\mathrm{c}} / \mathrm{dm}^{3}\right)$ & 1.03 & 3.71 & 3.63 & 3.12 \\
$\mathrm{Mg}^{2+}\left(\mathrm{cmol}_{\mathrm{c}} / \mathrm{dm}^{3}\right)$ & 0.12 & 1.15 & 1.12 & 0.9 \\
$\mathrm{Al}^{3+}\left(\mathrm{cmol}_{\mathrm{c}} / \mathrm{dm}^{3}\right)$ & 1.1 & 0.07 & 0.03 & 0.23 \\
$\mathrm{H}+\mathrm{Al}\left(\mathrm{cmol}_{\mathrm{c}} / \mathrm{dm}^{3}\right)$ & 7.3 & 5.93 & 4.9 & 6.2 \\
$\mathrm{SB}\left(\mathrm{cmol}_{\mathrm{c}} / \mathrm{dm}^{3}\right)$ & 1.19 & 5.21 & 4.97 & 4.24 \\
$\mathrm{CEC}-\mathrm{t}\left(\mathrm{cmol}_{\mathrm{c}} / \mathrm{dm}^{3}\right)$ & 2.29 & 5.27 & 5.01 & 4.48 \\
$\mathrm{CEC}-\mathrm{T}\left(\mathrm{cmol} / \mathrm{dm}^{3}\right)$ & 8.49 & 11.14 & 9.87 & 10.44 \\
$\mathrm{~V}(\%)$ & 14 & 46.83 & 51.13 & 40.6 \\
$\mathrm{~m}(\%)$ & 48 & 1.3 & 0.7 & 5.23 \\
Sand $(\mathrm{kg} / \mathrm{kg})$ & 0.12 & 0.16 & 0.19 & 0.17 \\
$\mathrm{Silt}(\mathrm{kg} / \mathrm{kg})$ & 0.07 & 0.09 & 0.10 & 0.08 \\
$\mathrm{Clay}(\mathrm{kg} / \mathrm{kg})$ & 0.84 & 0.75 & 0.71 & 0.75 \\
$\mathrm{Pd}\left(\mathrm{kg} / \mathrm{dm}^{3}\right)$ & 2.24 & 2.40 & 2.32 & 2.32 \\
\hline
\end{tabular}

Note. $\mathrm{NC}=$ native Cerrado; DP: disc plowing; $\mathrm{NT}=$ no-tillage; and DHS = disc harrow + subsoiler. Analyses: $\mathrm{pH}$ in water-ratio of 1:2.5; $\mathrm{P}$ and $\mathrm{K}$ using Mehlich-1 extractor; $\mathrm{Ca}^{2+} \mathrm{Mg}^{2+} \mathrm{Al}^{3+}$ with $\mathrm{KCl} 1 \mathrm{~mol} / \mathrm{L} ; \mathrm{H}+\mathrm{Al}$ with calcium acetate $0.5 \mathrm{~mol} / \mathrm{L}, \mathrm{pH} 7.0 ; \mathrm{SB}=$ sum of bases; $\mathrm{CEC}=$ cation exchange capability effective ( $\mathrm{t}$, at original $\mathrm{pH})$ and at $\mathrm{pH} 7.0(\mathrm{~T}) ; \mathrm{V}=$ base saturation; $\mathrm{m}=$ aluminum saturation; $\mathrm{Pd}=$ particle density. All procedures are according to EMBRAPA (2017).

\subsection{Methods and Techniques}

Disturbed and undisturbed samples were collected in July 2016. The disturbed samples from 0.00-0.20 m were obtained using an auger probe. Three composite samples were used per treatment, corresponding to 20 single samples collected per plot. In the laboratory, soil samples were sieved through a $2.0 \mathrm{~mm}$ sieve to obtain soil material for the analyses. The undisturbed samples were obtained using volumetric cylinders of approximately $0.05 \mathrm{~m}$ in height and diameter. In each treatment, six rings were collected in the center of the layer at a depth of $0.00-0.10 \mathrm{~m}$.

The soil mechanical resistance to penetration (RP) was evaluated in the field in February 2017 at a depth of up to $60 \mathrm{~cm}$ using a PenetroLOG digital penetrometer (model PLG1020; Falker), and measurements were performed every $0.01 \mathrm{~m}$ at a constant speed. The data were extracted from the storage unit using Penetro-LOG software and graphed and expressed by the mean values in $10 \mathrm{~cm}$ intervals, as follows: RP1 $(0-10 \mathrm{~cm}), \mathrm{RP} 2(10-20 \mathrm{~cm}), \mathrm{RP} 3$ $(20-30 \mathrm{~cm})$, RP4 $(30-40 \mathrm{~cm})$, RP5 $(40-50 \mathrm{~cm})$, and RP6 $(50-60 \mathrm{~cm})$.

Wet aggregate stability was evaluated in samples pre-moistened and shaken in a set of sieves of different mesh sizes. After agitation, the weight of the samples retained in each sieve was used to calculate the mean weight diameter (MWD) and geometric mean diameter (GMD) according to Embrapa (2017). 
Soil bulk density (Bd) was determined using the volumetric ring method, and particle density (Pd) was measured using the volumetric flask method. Microporosity (Mi) was determined in undisturbed samples after equilibrium to the $-0.006 \mathrm{MPa}$ on a tension table. Total porosity $(\mathrm{Pt})$ was estimated by the equation:

$$
P t=[1-(B d / P d)] \times 100
$$

Macroporosity (Ma) was calculated by the equation:

$$
M a=P t-M i
$$

Water-dispersible clay (WDC) was determined using the pipette method. The degree of flocculation (DF) relative to the total clay (TC) content was calculated according to the equation:

$$
D F=[(T C-W D C) / T C] \times 100
$$

All analyses were performed according to Embrapa (2017). The soil total organic carbon (TOC) was determined according to the Walkley \& Black method (Yeomans \& Bremner, 1988).

Physical fractionation of soil organic matter was carried out to obtain particulate organic matter (POM) and mineral-associated organic matter (MOM) according to the methodology proposed by Cambardella \& Elliott (1993). The TOC in the MOM (TOC-MOM) was determined according to Yeomans and Bremner (1988). The TOC in the POM (TOC-MOP) was obtained by subtracting the TOC-MOM from the total soil organic carbon.

The specific surface area $\left(\mathrm{m}^{2} / \mathrm{g}\right)$ of soil samples was quantified by measuring the water vapor sorption (Quirk, 1955).

The GRSP concentration, including the easily extractable glomalin (EEG) and total glomalin (TG), was determined according to Wright et al. (1996). For EEG processing, autoclaving was performed once. For TG, autoclaving was performed six times until the solution reached a light-yellow color. These two fractions were quantified by the Bradford (1976) colorimetric method using a spectrophotometer and bovine serum albumin as the standard.

\subsection{Statistical Analysis}

The data were subjected to analysis of variance to assess differences between the treatments after confirming the normality of residuals using the Shapiro-Wilk test $(p<0.05)$. Dunnett's posthoc test $(p<0.10)$ was used to compare the means of the treatments relative to the control area (NC). The mean values in the cultivated areas were compared using Tukey's test $(\mathrm{p}<0.10)$. All statistical analyses were performed using $\mathrm{R}$ software version 3.4 (R Core Team, 2017) and the "ExpDes.pt" package developed by Ferreira et al. (2009).

\section{Results and Discussion}

The soil physical and chemical attributes are shown in Table 2. The different management practices for more than 20 years changed around one-third of the soil attributes in comparison to the native Cerrado $(\mathrm{p}<0.10)$.

\subsection{Effects on Soil Structure}

The soil structure was used to access the soil physical quality because this parameter is highly sensitive to soil management practices. The native Cerrado area (NC) presented a larger and more stable aggregates as indicated by MWD and GMD values. Beutler et al. (2001) observed a similar result in an adjacent site of the present study. The authors verified higher GMD in the NC area, although the soil of no-tillage (NT) treatment has presented larger aggregates $(>2 \mathrm{~mm})$ in a proportion similar to that of the $\mathrm{NC}$ area at a depth of 0 to $5 \mathrm{~cm}$.

The removal of the native vegetation in the cultivated areas and the use of maintaining soil management practices for two decades reduced the average size of the aggregates, although the differences between the three cultivated areas (NT, DP, and DHS) were not significant. The presence of larger and more stable aggregates increases soil pre-consolidation pressure (Letey, 1985; Dexter, 1991), facilitates water infiltration by increasing macroporosity, and promotes water retention in micropores (Dexter, 1988).

The bulk density (Bd) increased with the land use and management in the three cultivated areas in comparison to the NC area. Nonetheless, we cannot find differences among the cultivated areas. The Bd value in soil with NT $\left(1.33 \mathrm{~kg} / \mathrm{dm}^{3}\right)$ was $56 \%$ higher than in the NC area $\left(0.85 \mathrm{~kg} / \mathrm{dm}^{3}\right)$. Increases in Bd values under NT systems have been reported in the literature (Sheehy et al., 2013; Domínguez \& Bedano, 2016). For this reason, is usual to recommend periodic and minimal tillage in NT soils to improve their physical properties. Considering that, Camara and Klein (2005) observed the reduction of Bd values and the increase of water infiltration in soils submitted to the scarification and managed under NT after six years. 
The soil porosity (P) was not decreased with cultivation using disc plowing compared with the $\mathrm{NC}$ area. However, these soil characteristics was reduced in NT soils and in the soils managed by harrowing and subsoiling. The increase in Bd in NT soils decreased the soil porosity, as reported in previous studies (Silveira et al., 1999; Silva et al., 2008). In contrast, an increase in soil porosity in the surface layer was observed by Loss et al. (2017) in vegetables grown under NT compared to conventional tillage, and this result was attributed to the higher number of roots and consequently higher occurrence of voids in the soil matrix. In turn, Costa et al. (2003) found no differences in total porosity, macroporosity and microporosity in a Brazilian Latosol managed in the long-term under NT and conventional tillage.

Table 2. Physical and chemical characteristics of a Brazilian Cerrado Latosol managed using different practices for more than 20 years

\begin{tabular}{llllll}
\hline & NC & DP & NT & DHS & CV \\
\hline MWD $(\mathrm{mm})$ & $2.36 \pm 0.07$ & $1.80^{*} \pm 0.04$ & $1.90^{*} \pm 0.07$ & $1.92^{*} \pm 0.06$ & 3.9 \\
GMD $(\mathrm{mm})$ & $1.86 \pm 0.10$ & $1.14^{*} \pm 0.06$ & $1.20^{*} \pm 0.07$ & $1.22^{*} \pm 0.05$ & 6.2 \\
Bd $\left(\mathrm{kg} / \mathrm{dm}^{3}\right)$ & $0.85 \pm 0.05$ & $1.14^{*} \pm 0.04$ & $1.33^{*} \pm 0.09$ & $1.14^{*} \pm 0.01$ & 7.9 \\
Total porosity $\left(\mathrm{m}^{3} / \mathrm{m}^{3}\right)$ & $0.62 \pm 0.01$ & $0.53 \pm 0.02$ & $0.42^{*} \pm 0.04$ & $0.51^{*} \pm 0.01$ & 9.7 \\
Microporosity $\left(\mathrm{m}^{3} / \mathrm{m}^{3}\right)$ & $0.34 \pm 0.02$ & $0.42^{*} \pm 0.00$ & $0.40^{*} \pm 0.02$ & $0.42^{*} \pm 0.01$ & 3.8 \\
Macroporosity $\left(\mathrm{m}^{3} / \mathrm{m}^{3}\right)$ & $0.28 \pm 0.02$ & $0.11^{*} \pm 0.02$ & $0.02^{*} \pm 0.02$ & $0.09^{*} \pm 0.01$ & 54.0 \\
WDC $(\mathrm{kg} / \mathrm{kg})$ & $0.07 \pm 0.01$ & $0.08 \pm 0.00$ & $0.09 \pm 0.02$ & $0.08 \pm 0.00$ & 27.5 \\
RP1 $(0-10 \mathrm{~cm})(\mathrm{MPa})$ & $0.23 \pm 0.03$ & $0.52 \mathrm{~b} \pm 0.06$ & $1.68 \mathrm{a}^{*} \pm 0.14$ & $0.20 \mathrm{c} \pm 0.02$ & 17.4 \\
RP2 $(10-20 \mathrm{~cm})(\mathrm{MPa})$ & $0.51 \pm 0.10$ & $2.48 \mathrm{~b}^{*} \pm 0.23$ & $3.44 \mathrm{a}^{*} \pm 0.22$ & $0.70 \mathrm{c} \pm 0.02$ & 13.07 \\
RP3 $(20-30 \mathrm{~cm})(\mathrm{MPa})$ & $0.65 \pm 0.13$ & $2.90 \mathrm{a}^{*} \pm 0.09$ & $3.22 \mathrm{a} \pm 0.31$ & $1.29 \mathrm{~b}^{*} \pm 0.26$ & 15.8 \\
RP4 $(30-40 \mathrm{~cm})(\mathrm{MPa})$ & $0.79 \pm 0.19$ & $2.68^{*} \pm 0.13$ & $2.47 \pm 0.12$ & $1.90^{*} \pm 0.40$ & 21.3 \\
RP5 $(40-50 \mathrm{~cm})(\mathrm{MPa})$ & $1.01 \pm 0.28$ & $2.02^{*} \pm 0.09$ & $1.90^{*} \pm 0.09$ & $1.88^{*} \pm 0.33$ & 18.3 \\
RP6 $(50-60 \mathrm{~cm})(\mathrm{MPa})$ & $1.31 \pm 0.34$ & $1.55 \pm 0.05$ & $1.54 \pm 0.10$ & $1.58 \pm 0.23$ & 17.2 \\
TOC $(\mathrm{g} / \mathrm{kg})$ & $44.32 \pm 2.11$ & $31.92^{*} \pm 2.71$ & $30.54^{*} \pm 2.32$ & $31.94 * \pm 1.64$ & 5.5 \\
TOC-MOM $(\mathrm{g} / \mathrm{kg})$ & $23.65 \pm 1.32$ & $21.55 \pm 1.62$ & $19.69 \pm 1.79$ & $21.35 \pm 2.17$ & 5.5 \\
TOC-POM $(\mathrm{g} / \mathrm{kg})$ & $20.67 \pm 3.02$ & $10.37^{*} \pm 1.09$ & $10.85 \pm 1.54$ & $10.59^{*} \pm 0.54$ & 34.0 \\
SS $\left(\mathrm{m}^{2} / \mathrm{g}\right)$ & $114.08 \pm 4.86$ & $98.40 \pm 4.59$ & $95.76 \pm 6.78$ & $95.24 \pm 4.37$ & 4.6 \\
\hline
\end{tabular}

Note. $\mathrm{NC}=$ native Cerrado; $\mathrm{DP}=$ disc plowing; $\mathrm{NT}=$ no-tillage system; $\mathrm{DHS}=$ disc harrow + subsoiler.

$\mathrm{MWD}=$ mean weight diameter; $\mathrm{GMD}=$ geometric mean diameter; $\mathrm{Bd}=$ bulk density; $\mathrm{WDC}=$ water-dispersible clay; $\mathrm{RP}=$ soil resistance to penetration; $\mathrm{TOC}=$ total organic carbon; TOC-MOM $=\mathrm{TOC}$ of the mineral-associated organic matter fraction; TOC-POM $=$ TOC of the particulate organic matter fraction; and SS $=$ soil specific surface area; Means followed by standard errors. $\mathrm{CV}=$ coefficient of variation in the cultivated areas (DP, NT, and DHS). Samples collected at a depth of 0 to $20 \mathrm{~cm}$, except for the evaluation of Bd (0-0.1 m) and RP. The means followed by an asterisk $\left(^{*}\right)$ were significantly different from the reference area (NC) using Dunnett's test $(p<0.10)$. For the cultivated treatments (DP, NT and DHS) the means followed by the same letter in each line were not significantly different using Tukey's test $(p<0.10)$.

The dynamics of soil macropores (Ma) and micropores (Mi) was affected by soil use and management. The removal of the $\mathrm{NC}$ and the implementation of treatments cultivated increased the Mi and decreased Ma. Under the NT system, there was a reduction in Ma values, reaching values of $0.02 \mathrm{~m}^{3} / \mathrm{m}^{3}$. Similarly, Stone and Silveira (2001) observed that Bd and Mi increase whereas Ma was decreased in NT soils in Brazilian Cerrado. Moreover, Costa et al. (2009) verified that Ma values were increased in a Humic Cambisol managed by plowing and harrowing during 15 years in comparison to soils under NT for nine years.

Soil structure affects the growth and development of crop roots. In this context, the analysis of soil Ma is essential because macropores are crucial for soil water infiltration and are the preferred route for root growth (Calonego et al., 2011). Given that the larger pores are the most affected during soil compaction, good management practices should be prioritized, especially for the traffic of agricultural machines (Bergamin et al., 2010).

Although the average size of aggregates (WMD and GMD) was decreased by adopting cultivation practices, even after two decades, these practices did not affect the clay flocculation. The change in inputs, the decrease in 
TOC and the mechanical practices used in the cultivated areas did not change the water dispersible clay (WDC) contents (NC: 91\%; DP: 90\%; NT: 88\% and DHS: 89\%). These results differ from those verified by Beutler et al., (2001) in an adjacent area, wherein WDC was increased with native Cerrado removal and after crops grown under NT and conventional tillage.

\subsection{Effect on Soil Mechanical Resistance to Penetration}

Soil compaction is related to increases in $\mathrm{Bd}$ values and soil mechanical resistance to penetration (RP). The RP (Figure 1) was increased in the cultivated areas, especially under NT and DP treatments. In contrast, the annual use of DHS reduced RP and did not decrease the aggregate size, soil porosity and Bd compared with the other two soil preparation method (Table 2).

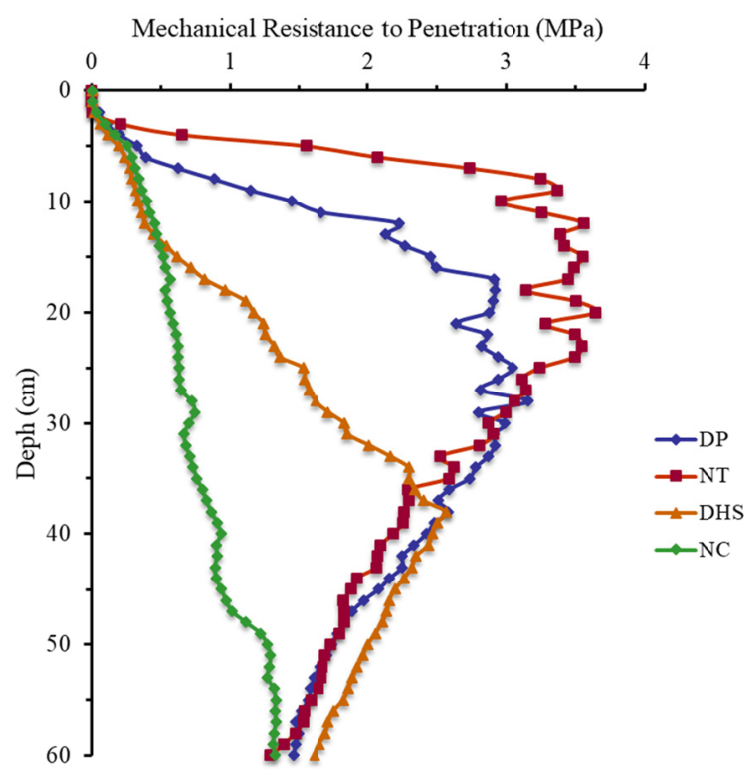

Figure 1. Soil resistance to penetration in a Cerrado Latosol under different land management after more than 20 years. $\mathrm{NC}=$ native Cerrado; $\mathrm{DP}=$ disc plowing; $\mathrm{NT}=$ no-tillage system. $\mathrm{DHS}=$ disc harrow + subsoiler. The assessment was performed in February 2017 (rainy season)

The use of the DHS provided similar RP values to those found for the NC area up to $15 \mathrm{~cm}$ depth (Figure 1). From $15 \mathrm{~cm}$ RP is increased with the depth in DHS treatment, reaching the similar values of areas managed by DP and NT at a depth of 35-40 cm. Subsoiling can improve root growth conditions as observed by Seixas et al., (2005), who verified higher vertical and horizontal distribution of roots at the end of corn cultivation. The authors also noticed the root growth was not limited to a depth of $30-40 \mathrm{~cm}$ after subsoiling as previously observed in compacted soil.

Others studies show benefits of subsoiling to the soil structure under certain conditions. After ten years of cultivation Tian et al. (2014) observed that subsoiling combined with the maintenance of straw on the soil was as efficient as NT in improving the soil physical quality in China, leading to higher accumulation of carbon in stable macroaggregates and increased levels of soil total organic carbon.

Previous studies demonstrated the occurrence of subsurface compaction in NT systems. Camargo and Alleoni (1997) recommend the use of subsoiling to disrupt these layers without performing soil inversion and considering at the depth not reached by plow and scarificator. Similarly, Seki et al. (2015) recommend the practice of subsoiling in NT systems because its effects persist after harvesting. and Bd values are lower than those before the procedure.

Martínez et al. (2011) observed that compaction was decreased by subsoiling in NT areas and promote the highest crop yield in oat-wheat rotation compared to the other evaluated treatments. The same authors suggest that the use of conservative practices such as NT should be monitored and intervention is recommended when compaction occurs.

The RP values evaluated at successive depths of $10 \mathrm{~cm}$ (Table 2) showed differences among the three cultivated areas (DP, NT and DHS) compared to the NC area at all depths, except for the highest one $(50-60 \mathrm{~cm})$. From 0 to 
$50 \mathrm{~cm}$ no-tillage promote higher RP values than the reference area (NC). Soil resistance to penetration with disc plowing and disc harrow and subsoiler was higher than that in the native Cerrado at a depth of 10-50 cm and 20-50 cm, respectively. In the soil superficial layer $(0-10 \mathrm{~cm})$, the lower values of RP with DP and DHS may be due to soil tillage during soil preparation for cultivation.

In general, cultivation practices increase the soil resistance to penetration until $50 \mathrm{~cm}$ depth. The no-tillage system presented the highest RP values until $30 \mathrm{~cm}$ depth whereas DHS-treated soils presented the lowest RP (Table 2). No differences among cultivated areas (NT, DP and DHS) were diagnosed after $30 \mathrm{~cm}$ depth. Treatments with soil revolving (DP and DHS) presented similar soil resistance to penetration to reference area (NC) in the superficial layer studied (RP1). Disc plowing treatment exhibited high resistance to penetration at 21-30 cm depth, coinciding with the depth of cut of disc plow.

The soil resistance to penetration verified at the no-tillage area is coherent with the $\mathrm{Bd}$ values. These results suggest the formation of a "no-till pan" as proposed by Reichert et al. (2009), which usually develops under long-term no-tillage and is commonly found at of 7-20 cm depth. These authors characterize this layer with high mechanical strength, high bulk density and low porosity. Hamza and Anderson (2005) highlight the preference of some farmers for conventional tillage over no-tillage systems because although can increase soil organic matter, it is common to find critical values of RP (>2 MPa) in no-tillage areas and severe restrictions to root growth can be observed. However and in contrast to this restrictions, most parts of Brazilian farmers consider no-tillage promotes economic environmental and social benefits and its adoption is more than $50 \%$ of the cultivated area with annual crops (Freitas \& Landers, 2014).

Our results show around 3.5 MPa as the higher RP found. The critical value of RP varies among crops and for corn 1.5 to $4.0 \mathrm{MPa}$ are usually considered critical, although values of $1.3 \mathrm{MPa}$ can reduce $50 \%$ of plant growth (ROSOLEM et al., 1999).

Soil moisture should be considered when evaluating RP Lower RP values in the native Cerrado and the use of DHS coincided with higher soil moisture (Table 3). In turn, higher RP values in no-tillage and disc plowing treatments were coincident with lower moisture. Therefore, considering that the treatments were close, without evidence of differences in rainfall, the maintenance of higher soil moisture was only achieved in the areas managed with harrow with the subsoiler.

It is well known that resistance to penetration depends on soil $\mathrm{Bd}$ and moisture. We can assume that the differences in RP values were due to soil moisture because there were no differences in Bd among the three cultivated areas (Table 2). Therefore, a linear relationship between RP and soil moisture (Figure 2) indicates that a $1 \%$ rise in gravimetric moisture decrease in $\mathrm{RP}$ of $0.1 \mathrm{MPa}$.

Table 3. Gravimetric water content during the mechanical resistance to penetration measurement

\begin{tabular}{lllll}
\hline \multirow{2}{*}{ Layer $(\mathrm{cm})$} & \multicolumn{4}{c}{ Gravimetric Moisture } \\
\cline { 2 - 5 } & $\mathrm{NC}$ & DP & NT & DHS \\
\hline $0-20$ & 0.40 & 0.21 & 0.22 & 0.36 \\
$20-40$ & 0.42 & 0.26 & 0.26 & 0.32 \\
$40-60$ & 0.35 & 0.28 & 0.28 & 0.27 \\
\hline
\end{tabular}




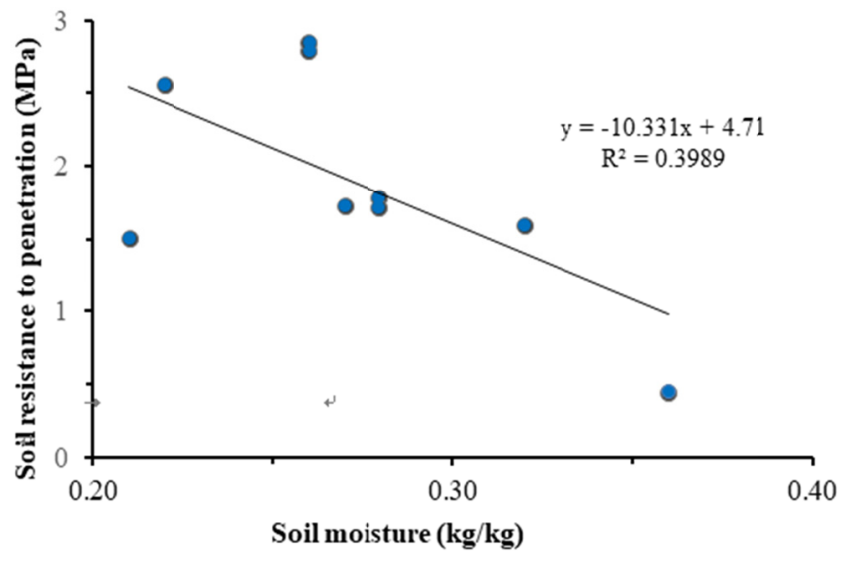

Figure 2. Relationship between soil mechanical resistance to penetration (MPa) and soil moisture $(\mathrm{kg} / \mathrm{kg}$ ) in Cerrado Latosol managed using different practices for more than 20 years (Disc Plowing; No-Tillage and Disc Harrow + Subsoiler)

\subsection{Effects on Soil Carbon Dynamics}

Removing the native Cerrado reduced the soil TOC in the three cultivation areas (NT, DP and DHS) (Table 2). The maintenance of straw on the surface at the end of each harvest with the use of no-tillage was not enough to increase soil TOC and the NT system presented similar TOC contents to those in DP and DHS treatments. The expected high performance of the NT system concerning increase TOC contents was not verified. This result diverges to Costa et al. (2009) who observed that tillage using a disc plow and disc harrow in an integrated crop-livestock system decreased TOC relative to the NT system.

We would remark that the TOC data were shown in terms of mass $(\mathrm{g} / \mathrm{kg})$ although most studies performed measurements using volume measurement $\left(\mathrm{g} / \mathrm{dm}^{3}\right)$. However, even considering the results as volume the trend of lower TOC associated with NT was maintained. The data transformed using the soil bulk density resulted in the following TOC contents: NC: $38.12 \mathrm{~g} / \mathrm{dm}^{3}$; DP: $30.32 \mathrm{~g} / \mathrm{dm}^{3}$; NT: $29.76 \mathrm{~g} / \mathrm{dm}^{3}$ and DHS: $30.34 \mathrm{~g} / \mathrm{dm}^{3}$.

The limitation in maintaining the straw on the soil surface in no-tillage systems may explain the obtained results. Bernardi et al. (2003) reported that keeping straw on the soil surface in NC areas is limited by climatic conditions, where it favors organic matter decomposition and command the absence of winter crops because of water scarcity. However, the same authors no longer consider these problems as obstacles in the Cerrado because early summer cultivars are available allowing growing off-season crops.

Most of the soil organic carbon was associated with TOC-MOM as also reported by Balin et al. (2017) and Loss et al. (2009). This organic matter fraction accounts for $53 \%$ of the carbon in the NC area and $64-67 \%$ in the three cultivated areas (NT, DP and DHS). These results indicate that cultivation increased TOC-MOM and decreased TOC-POM. After more than 20 years TOC-MOM was two-fold higher than TOC-POM in the cultivated areas.

\subsection{Effect on Soil Specific Surface Area}

The specific surface area is strongly correlated with soil attributes, including organic matter clay content. and clay fraction mineralogy (Brunauer, 1943). Specific surface area reflects the soil reactivity to different physical-chemical phenomena. Although the native Cerrado soil presented a higher clay concentration (Table 1) and higher organic carbon content (Table 2) than the other evaluated cultivation areas. There were no differences between NC and cultivated (NT, DP and DHS) areas. However, we diagnosed the expected correlation between specific surface area and TOC $(r=0.76 . p<0.01)$ and clay $(r=0.67 . p<0.01)$ contents.

The hypothesis not proven in the present study was that no-tillage system could always increase soil surface area by increasing soil organic carbon.

\subsection{Effect on Glomalin-Related Soil Protein}

Glomalin is a glycoprotein released by arbuscular mycorrhizal fungi and has a vital role in forming and stabilizing soil aggregates (Franzluebbers et al., 2000). In this study, two protein fractions - easily extractable glomalin (EEG) and total glomalin (TG) - were evaluated. While EEG is more recently deposited in the soil. TG is composed of different substances with varying levels of recalcitrance. 
The cultivation treatments (NT, DP and DHS) did not change the soil EEG contents in comparison to the native Cerrado, but we found differences among cultivated treatments (Figure 3). Considering conventional practices, disc plowing provides more EEG soil contents than harrowing + subsoiling; however, the difference was slightly and with little or no practical relevance.

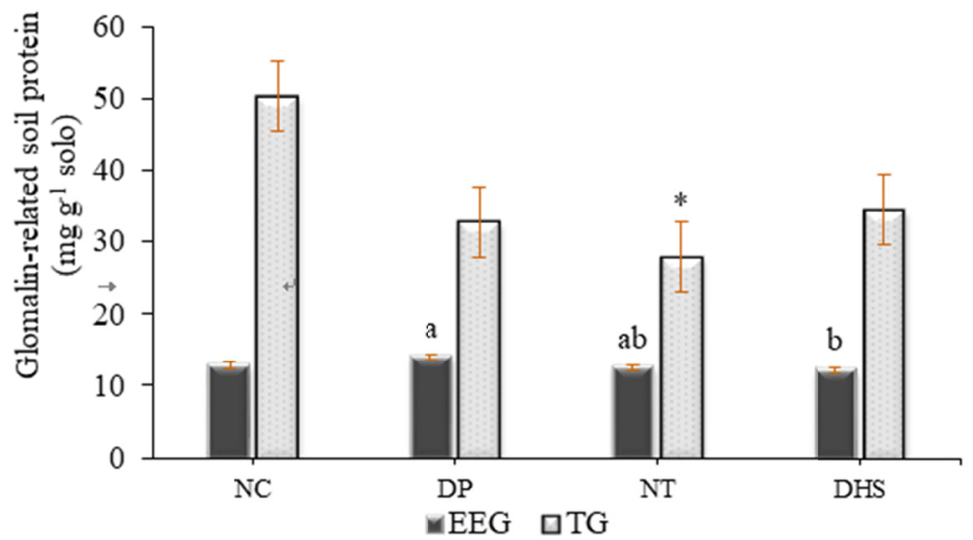

Figure 3. Easily extractable glomalin (EEG) and total glomalin (TG) contents in a Cerrado Latosol conducted by different soil management strategies for more than 20 years. $\mathrm{NC}=$ native Cerrado; $\mathrm{DP}=$ disc plowing; NT: no-tillage system; DHS = disc harrow + subsoiler. The bars indicate the standard error of the mean. For the same variable in the cultivated areas (DP, NT and DHS), the values with the same letter in each column were not significantly different among each other using Tukey's test $(p<0.10)$. The values in asterisks $(*)$ indicated significant differences between the cultivated areas (DP, NT and DHS) and the native Cerrado (NC) area using Dunnett's test $(\mathrm{p}<0.10)$

There were no differences in soil TG contents between the three cultivated areas (NT, DP and DHS) after 20 years of soil management. The soil TG contents were decreased in no-tillage treatment compared with native Cerrado. Nonetheless, Goss, and Varennes (2002) observed that the colonization of mycorrhizae in NT and minimum-tillage systems was increased, providing higher TG contents compared with a conventional tillage system evaluated. The increase in soil TG is usually expected after adopting sustainable practices such as no-tillage. These practices may favor the long-term development of soil microorganism by increasing food and energy resources and reducing environmental disturbance (Wang et al., 2017).

\subsection{Effects on Soil Physical Quality}

The results indicated that the decline in soil physical quality was similar among the three soil management strategies (NT, DP and DHS) even after more than two decades of intensive use. The soil physical resilience of the clayey and very clayey Oxisols from the Brazilian Cerrado is well documented in the literature and is related to the long-term stability of the soil microstructure, provided by pedogenetic processes over time and the action of physical, chemical and biological agents on oxidic matrix (Schaefer, 2001; Oliveira et al., 2017).

The failure of the no-tillage system to provide better physical conditions than the other two soil management practices evaluated in the present study may be related to the difficulty in keeping the straw on the soil surface. Therefore, the NT system studied fails with one of the three components of these conservation systems, because minimal soil disturbance and crop rotation are commonly adopted. This situation can be common in tropical regions with dry winter and where irrigation is limited. Although this treatment should not be considered a traditional no-tillage system, it represents the strategy used in many areas of Cerrado region of Central Brazil. where no winter crops are used and the sowing is performed directly on the remains of dried weeds. In this region, this procedure is widely used as no-tillage and is the primary form of soil management. The difficulty in maintaining straw on the soil surface in regions of Central Brazil because of the absence of rainfall from May to August was reported by Alvarenga et al. (2008), who highlighted that the great challenge in these areas is to maintain the minimum of desirable straw on the soil surface, which should never be less than $4.0 \mathrm{t} / \mathrm{ha}$.

\section{Conclusions}

Removal of the native Cerrado vegetation and intensive cultivation for more than two decades impact similarly on soil physical quality independently of the soil management system used. 
Improvements in the physical quality of no-tillage system are limited when maintaining straw on the soil surface is unfeasible because of climate restrictions.

\section{Acknowledgements}

The authors are grateful for financial support of the Fundação de Amparo à Pesquisa do Estado de Minas Gerais-FAPEMIG-Brasil (Code APQ-00887-17) and Coordenação de Aperfeiçoamento de Pessoal de Nível Superior-CAPES, Brasil) (Finance Code 001), and for scholarship to the first author from the Programa de Estudantes-Convênio de Pós-graduação (PEC-PG, CAPES). Thanks also to Embrapa Milho e Sorgo for the support in the experimental area.

\section{References}

Alvarenga, R. C., Cruz, J. C., \& Viana. J. H. M. (2008). Cultivo do milho: Plantas de cobertura de solo (4th ed.). Embrapa Milho e Sorgo, Sistemas de Produção. Retrieved from https://ainfo.cnptia.embrapa.br/digital/ bitstream/item/35330/1/Plantas-cobertura

Andrews, S. S., Karlen, D. L., \& Mitchell, J. P. (2002). A comparison of soil quality indexing methods for vegetable production systems in Northern California. Agriculture Ecosystems \& Environment, 90, 25-45. https://doi.org/10.1016/S0167-8809(01)00174-8

Balin, N. M., Ziech. A. R. D., De Oliveira. J. P. M., Girardello. V. C., Stumpf. L., \& Conceição, P. C. (2017). Frações da materia orgânica, Índice de manejo do carbono e atributos físicos de um Latossolo Vermelho sob diferentes sistemas de uso. Revista Scientia Agraria, 18, 85-94. https://doi.org/10.5380/rsa.v18i3.53114

Bergamin, A. C., Vitorino, A. C. T., Franschini, J. C., Souza, C. M. A., \& Souza, F. R. (2010). Compactação em um Latossolo vermelho distroférrico e suas relações com o crescimento radicular do milho. Revista Brasileira de Ciência do Solo, 34, 681-691. https://doi.org/10.1590/S0100-06832010000300009

Bernardi, A. C. C., Machado, P. L. O. A., Freitas. P. L., Coelho, M. R., Leandro, W. M., Oliveira Junior. J. P., ... Carvalho, M. C.S. (2003). Correção do solo e adubação no sistema de plantio direto nos Cerrados (p. 22, Embrapa Solos, Documentos 46). Rio de Janeiro: Embrapa Solos. http://ainfo.cnptia.embrapa.br/digital/ bitstream/item/60852/1/doc-46-2003.pdf

Beutler, A. N., Silva, M. L. N., Curi, N., Ferreira, M. M., Pereira, F. I. A, \& Cruz, J. C. (2001). Agregacão de Latossolo Vermelho distrófico típico relacionada com o manejo na região dos Cerrados no Estado de Minas Gerais. Revista Brasileira de Ciência do Solo, 25, 129-136. https://doi.org/10.1590/S0100-0683200100010 0014

Bradford, M. M. (1976). A rapid and sensitive method for the quantitation of microgram quantities of protein utilizing the principle of protein-dye binding. Analytical Biochemistry, 72, 248-254. https://doi.org/10.1016/ 0003-2697(76)90527-3

Brunauer, S. (1943). The adsorption of gases and vapors. Physical adsorption. London, Princeton Univ. Press.

Calonego, J. C., Gomes, T. C., Santos. C. H., \& Tiritan, C. S. (2011). Desenvolvimento de plantas de cobertura em solo compactado. Bioscience Journal, 27, 289-296.

Camara, R. K., \& Klein, V. A. (2005). Escarificação em plantio direto como técnica de conservação do solo e da água. Revista Brasileira de Ciência do Solo, 29, 789-796. https://doi.org/10.1590/S0100-0683200500050 0014

Camargo, O., \& Alleoni, L. R. F. (1997). Compactação do solo e o desenvolvimento das plantas (p. 132). Piracicaba, SP: ESALQ.

Cambardella, C. A., \& Elliott, E. T. (1993). Methods for physical separation and characterization of soil organic matter fractions. Geoderma, 56, 449-457. https://doi.org/10.1016/B978-0-444-81490-6.50036-4

Costa, A., Albuquerque, J. Mafra, A. L., \& Silva, F. R. (2009). Propriedades físicas do solo em sistemas de manejo na integração lavoura-pecuária. Revista Brasileira de Ciência do Solo, 33, 235-244. https://doi.org/ 10.1590/S0100-06832009000200001

Costa, F. S., Albuquerque, J. A., Bayer, C., Fontoura, S. M. V., \& Wobeto, C. (2003). Propriedades físicas de um Latossolo bruno afetadas pelos sistemas de plantio direto e preparo convencional. Revista Brasileira de Ciencia do Solo, 27, 527-535. https://doi.org/10.1590/S0100-06832003000300014 
Davis, C. M., \& Fox, J. F. (2009). Sediment fingerprinting: review of the method and future improvements for allocating nonpoint source pollution. Journal of Environmental Engineering, 135, 490-504. https://doi.org/ 10.1061/(ASCE)0733-9372(2009)135:7(490)

Dexter, A. R. (1988). Advances in characterization of soil structure. Soil and Tillage Research, 11, $199-238$. https://doi.org/10.1016/0167-1987(88)90002-5

Dexter, A. R. (1991). Amelioration of soil by natural processes. Soil and Tillage Research, 20, 87-100. https://doi.org/10.1016/0167-1987(91)90127-J

Doetterl, S., Berhe, A. A., Nadeu, E., Wang, Z., Sommer. M., \& Fiener, P. (2016). Erosion deposition and soil carbon: A review of process level controls experimental tools and models to address $\mathrm{C}$ cycling in dynamic landscapes. Earth-Science Reviews, 154, 102-122. https://doi.org/10.1016/j.earscirev.2015.12.005

Domínguez, A., \& Bedano, J. C. (2016). The adoption of no-till instead of reduced tillage does not improve some soil quality parameters in Argentinean Pampas. Applied Soil Ecology, 98, 166-176. https://doi.org/ 10.1016/j.apsoil.2015.10.014

Doran, J. W., Coleman, D. C. Bezdicek, D. F., \& Stewart, B. A. (1994). Defining Soil Quality for a Sustainable Environment (pp. 3-21). SSSA, Madison, WI. https://doi.org/10.1017/S0889189300006123

EMBRAPA (Empresa Brasileira de Pesquisa Agropecuária). (2017). Manual de Métodos de Análise de Solo (3rd ed., p. 573). Brasília, DF: Embrapa.

FEBRAPDP (Federação Brasileira de Plantio Direto e Irrigação). (2018). Evolucão da área cultivada no sistema de plantio direto na palha-Brasil. Retrieved from https://febrapdp.org.br/download/EVOLUCAO_DO_ SPD_NO_PARANA_2014.pdf

Ferreira, E. B., Cavalcanti, P. P., \& Nogueira, D. A. (2009). Função em código R para analisar experimentos em $D B C$ simples em uma só rodada. Jornada Cientifica da Universidade Federal de Alfenas-MG, Alfenas, Resumos. Alfenas: Unifal-MG.

Franzluebbers, A. J., Wright, S. F., \& Stuedemann, J. A. (2000). Soil aggregation and glomalin under pastures in the Southern Piedmont USA. Science Society of America Journal, 64, 1018-1026. https://doi.org/10.2136/ sssaj2000.6431018x

Freitas, P. L., \& Landers, J. N. (2014). The Transformation of Agriculture in Brazil Through Development and Adoption of Zero Tillage Conservation Agriculture. International Soil and Water Conservation Research, 2, 35-46. https://doi.org/10.1016/S2095-6339(15)30012-5

Goss, M. J., \& Varennes, A. (2002). Soil disturbance reduces the efficacy of mycorrhizal associations for early soybean growth and $\mathrm{N}_{2}$ fixation. Soil Biology Biochemistry, 34, 1167-1173. https://doi.org/10.1016/S00380717(02)00053-6

Guo, L. J., Zheng, S. X., Cao, C. G., \& Li. C. F. (2016). Tillage practices and straw-returning method affect topsoil bacterial community and organic $\mathrm{C}$ under a rice-wheat cropping system in central China. Scientific Reports, 6, 6-33155. https://doi.org/10.1038/srep33155

Hamza, M. A., \& Anderson, W. K., (2005). Soil compaction in cropping systems: A review of the nature. causes and possible solutions. Soil Tillage Res, 82, 121-145. https://doi.org/10.1016/j.still.2004.08.009

Horn, R. (1988). Compressibility of arable land. Catena, 11, 53-71.

Iqbal, M., Hassan, A. U., Ali, A., \& Rizwanullah, M. (2005). Residual effect of tillage and farm manure on some soil physical properties and growth of wheat (Triticum aestivum L.). International Journal of Agriculture and Biology, 7, 54-57.

Letey, J. (1985). Relationship between Soil Physical Properties and Crop Production. In B. A. Stewart (Eds.), Advances in Soil Science (vol 1, pp. 277-294). Springer, New York, NY. https://doi.org/10.1007/978-1-46 12-5046-3_8

Loss, A., Junior, E. S., Schmitz, D., Veiga, M., Kurtz, C., \& Comin, J. J. (2017). Atributos físicos do solo em cultivo de cebola sob sistemas de plantio direto e preparo convencional. Revista Colombiana de Ciencias Hortícolas, 11, 105-113. https://doi.org/10.17584/rcch.2017v11i1.6144

Loss, A., Pereira, M. G., Schultz, N., Anjos, L. H. C., \& Silva, E. M. R. (2009). Carbono e frações granulométricas da matéria orgânica do solo sob sistemas de produção orgânica. Ciência Rural, 39, 78-83. https://doi.org/10.1590/S0103-84782009005000036 
Martínez, I., Ovalle, C., Del Pozo, A., Uribe, H., Valderrama, N., Prat. C., Sandoval, M., Fernandez, F., \& Zagal, E. (2011). Influence of conservation tillage and soil water content on crop yield in dryland compacted Alfisol of Central Chile. Chilean Journal of Agriculture Research, 71, 615-622. https://doi.org/10.4067/ S0718-58392011000400018

Ogban, P. I., Ekanem, T. P., \& Etim, E. A. (2001). Effect of mulching methods on soil properties and growth and yield of maize in Southeastern Nigeria. Tropical Agriculture (Trinidad), 78, 82-89.

Oliveira, V. A., Jacomine, P. K. T., \& Couto, E. G. (2017). Solos do Bioma Cerrado. In N. Curi, R. F. Novais, P. Vidal-Torrado, \& C. E. G. R. Schaefer (Eds.), Pedologia: Solos dos Biomas Brasileiros (pp. 177-226). Viçosa, MG: SBCS.

Quirk, J. P. (1955). Significance of surface areas calculated from water vapour sorption isotherms by the use of BET equation. Soil Science, 80, 423-430. https://doi.org/10.1097/00010694-195512000-00001

Reichert, J. M., Kaiser, D. R., Reinert, D. J., \& Riquelme, U. F. B. (2009). Variação temporal de propriedades físicas do solo e crescimento radicular de feijoeiro em quatro sistemas de manejo. Pesquisa Agropecuária Brasileira, 44, 310-319. https://doi.org/10.1590/S0100-204X2009000300013

Rosolem, C. A., Fernandez, E. M., Andreotti, M., \& Crusciol, C. A. C. (1999). Crescimento radicular de plântulas de milho afetado pela resistência do solo à penetração. Pesquisa Agropecuária Brasileira, 34, 821-828. https://doi.org/10.1590/S0100-204X1999000500013

Schaefer. C. E. R. (2001). Brazilian latosols and their B horizon microstructure as long-term biotic constructs. Australian Journal of Soil Research, 39, 909-926. https://doi.org/10.1071/SR00093

Seixas, J., Roloff, G., \& Ralisch, R. (2005). Tráfego de máquinas e enraizamento do milho em plantio direto. Ciência Rural, 35, 794-798. https://doi.org/10.1590/S0103-84782005000400007

Seki, A. S., Seki, F. G., Jasper, S. P., Silva, P. R. A., \& Benez, S. H. (2015). Efeitos de práticas de descompactacão do solo em área sob sistema plantio direto. Revista Ciência Agronômica, 46, 460-468. https://doi.org/10.5935/1806-6690.20150027

Sharifi, Z., Azadi, N., Rahimi, S., \& Certini, G. (2018). The response of glomalin-related soil proteins to fire or tillage. Geoderma, 329, 65-72. https://doi.org/10.1016/j.geoderma.2018.05.008

Sheehy, J., Six, J., Alakukku, L., \& Regina, K. (2013). Fluxes of nitrous oxide in tilled and no-tilled boreal arable soils. Agriculture, Ecosystems \& Environment, 164, 190-199. https://doi.org/10.1016/j.agee.2012.10.007

Silva, J. H., Silveira, P. M., \& Oliveira, J. P. (2008). Alterações na densidade e na porosidade de um Latossolo cultivado com feijão causadas pelo sistema de preparo do solo (IAC Documentos 85). Congresso Nacional de Pesquisa de Feijão, Campinas, Ciência e tecnologia na cadeia produtiva do feijão. Campinas: IAC.

Silveira, P. M., Silva, J. G., Stone, L. F., \& Zimmermann, F. J. P. (1999). Alterações na densidade e na microporosidade de um Latossolo Vermelho-Escuro causadas pelo sistema de preparo do solo. Pesquisa Agropecuária Tropical, 29, 145-149.

Spera, S. T., Santos, H. P., Fontaneli, R. S., \& Tomm, G. O. (2004). Efeitos de sistemas de produção de grãos envolvendo pastagens sob plantio direto nos atributos físicos de solo e na produtividade. Revista Brasileira de Ciência do Solo, 28, 533-542. https://doi.org/10.1590/S0100-06832004000300014

Stone, L. F., \& Silveira, P. M. (2001). Efeitos do sistema de preparo e da rotação de culturas na porosidade e densidade do solo. Revista Brasileira de Ciência do Solo, 25, 395-401. https://doi.org/10.1590/S010 0-06832001000200015

Tian, S., Wang, Y., Ning, T., Li, N., Zhao, H., Wang, B., Li, Z., \& Chi, S. (2014). Continued no-till and subsoiling improved soil organic carbon and soil aggregation levels. Agronomy Journal, 106, 212-218. https://doi.org/10.2134/agronj2013.0288

Wang, Y., Chunyue, L., Cong, T., Greg, D. H., Jared, L., DeForest., \& Shuijin, H. (2017). Long-term no-tillage and organic input management enhanced the diversity and stability of soil microbial community. Science of the Total Environment, 609, 341-347. https://doi.org/10.1016/j.scitotenv.2017.07.053

Wright, S. F., \& Upadhyaya, A. (1996). Extraction of an abundant and unusual protein from soil and comparison with hyphal protein of arbuscular mycorrhizal fungi. Soil Science, 161, 575-586. https://doi.org/10.1097/ 00010694-199609000-00003

Yeomans, J. C., \& Bremner, J. M. (1988). A rapid and precise method for routine determination of organic 
carbon in soil. Communications in Soil Science and Plant Analysis, 19, 1467-1476. https://oi.org/10.1080/ 00103628809368027

Zhang, X., Xiuli, X., Zhu, A., Zhang, J., \& Yang, W. (2017). Effects of tillage and residue managements on organic $\mathrm{C}$ accumulation and soil aggregation in a sandy loam soil of the North China Plain. Catena, 156, 176-183. https://doi.org/10.1016/j.catena.2017.04.012

\section{Copyrights}

Copyright for this article is retained by the author(s), with first publication rights granted to the journal.

This is an open-access article distributed under the terms and conditions of the Creative Commons Attribution license (http://creativecommons.org/licenses/by/4.0/). 